\title{
サステナブルビル構造システム PARTIAL FRAME TEST OF の部分架構実験 SUSTAINABLE BUILDING STRUCTURAL SYSTEM
}

\author{
島 有希子 $-* 1$ \\ 加藤貴志— $* 3$ \\ 岩田 衛—— \\ キーワード: \\ サステナビリティ, リュース, 柱梁接合部, ボルト接合, 座屈拘束ブレース, \\ 損傷制御構造, 床
}

Keywords :

Sustainability, Re-use, Beam-to-column connection, Bolted connection, Buckling-restrained brace, Damage-controlled-structure, Floor

\author{
Yukiko SHIMA - $* 1$ \\ Takashi $\mathrm{KATOH}-* 3$ \\ Mamoru IWATA — $* 5$
}

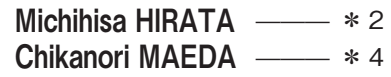

Loading tests for sustainable building structural system on the past studies have not considered the axial force applied to the beam-to-column connection. These tests have also not considered the change in the rigidity with the floor. Therefore, the effectiveness of the axial force and the floor was indefinite. This study verifies the effectiveness of the floor and the axial force by the behavior of the specimens that set partial frames for sustainable building structural system of one layer one span.

\section{1. サステナブルビル構造システムの概要}

建築鋼構造分野からの地球環境負荷削減を目指して、構造全体の 長寿命化を第一に考え、それが叶わない場合には容易に解体し、さ らに部材のリユースを可能とする「サステナブルビル構造システム (図1)」を研究している112)3)

サステナブルビル構造システムの柱梁接合方法は、従来のラーメ ン構造の剛接合などとは異なり、梁部材端部に溶接された接合部二 ニットから柱部材のフランジ部に鋼棒を通し、鋼棒に初期張力を導 入することで締め付けて接合するものである。この柱梁接合方法は、 柱梁接合部に生じる曲げモーメントの大きさにより、鋼棒に導入さ れた初期張力が解消され柱梁接合部が離間を開始するまでが剛接合 その後に接合部ユニット内の全ての鋼棒が完全に塑性化するまでが 半剛接合、さらに鋼棒の塑性化が進むとピン接合になり、接合状態 が段階的に変化するメカニズムを有している。接合部に生じる曲げ モーメントに応じて剛性が段階的に変化することで、使用時に要求 される剛性と、大地震時に要求される変形性能を両立している。

この構造システムでは、主架構を塑性化させないことを目的とし た柱梁接合部のメカニズムにより、主架構と地震エネルギー吸収部 材をより明確に分離することができる損傷制御構造4)の一形式であ る。すなわち、大地震時であっても接合部が回転性能を有するため、 地震力を方杖状に設置した制振部材としての座屈拘束ブレースのみ によって吸収し、主架構である柱部材と梁部材を弾性域に留めるこ とができる。そして、大地震後には損傷した座屈拘束ブレースのみ を点検、必要に応じて取替えることにより主架構を継続使用するこ とができる。

\section{2. 実験の目的}

現在までに、この構造システムの柱梁接合部の力学的特性は、図 2 に示すような $\mathrm{T}$ 字型試験体の実験により明らかにされた 2)。また、 この柱梁接合部の力学的特性を解析においてほぼ正確に表現できる 力学モデルが構築された ${ }^{3)}$ 。

ところで、鋼構造建物において床部材が緊結された合成梁は、断 面の中立軸が梁成の中心よりも上にあるため、柱梁接合部に大きな 影響を与える。ここでは、本システムにおける合成梁の効果につい て検証するために、 1 層 1 スパンのサステナブルビル構造システム の部分架構の床なしと床ありの試験体について載荷実験を行う。実 験において $\mathrm{T}$ 字型試験体では考慮できなかった、複数の柱部材や床 部材を設置した場合の柱梁接合部の挙動も分析する。加えて、試験 体をモデル化したものを解析し、実験結果と比較することで床部材 の影響を含め、既往の解析法 3)の妥当性を検証する。

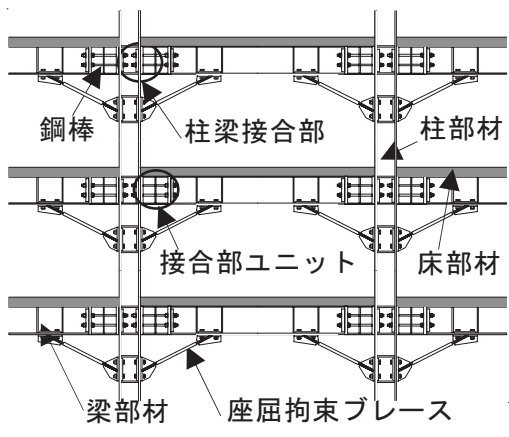

図 1 構造システム

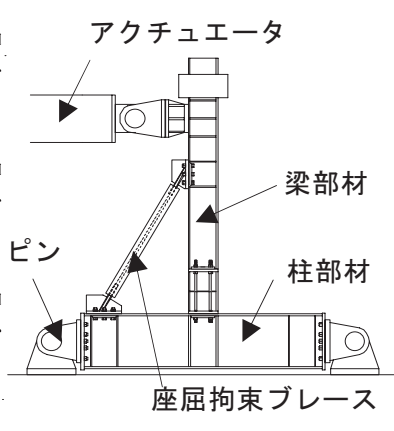

図 2 字型試験体

本報告は，文献 7 ) で発表したものに実験データ及び解析データを追加してまとめたものである。

*1 神奈川大学工学研究科 大学院生

（=221-8686 横浜市神奈川区六角橋3-27-1)

*2 神奈川大学工学研究科 大学院生 (当時)

*3 テンポール(株) 取締役

*4 前田親範一級建築士事務所 代表

*5 神奈川大学工学部建築学科 教授.工博

Graduate Student, Dept. of Architecture and Building Eng., Kanagawa Univ.

* 2 Former Graduate Student, Dept. of Architecture and Building Eng., Kanagawa Univ.

*3 Director, Tenpole. Co., LTD.

*4 Representative, Maeda office

*5 Prof., Dept. of Architecture and Building Eng., Kanagawa Univ., Dr Eng. 


\section{3. 実験計画}

\section{1 試験体考案}

従来の試験体は、図 2 に示すような柱梁接合部を 90 度回転させ取 り出したT字型になっており、柱部材両端をピン支持としたもので あった。そのため、実際の骨組み中では生じると思われる柱による 梁軸方向変形の拘束力や、床部材の設置による梁部材の軸応力の増 加などを考慮していなかった。それゆえ、この構造システムを用い て実際に設計する建物における、柱梁接合部の挙動については不明 確な所があった。

ここでは複数の柱部材を考慮し、床部材を設置した試験体を既往 の研究5) 6)等を参考にして設定する(図3)。柱部材端部で塑性化が生 じエネルギー吸収をさせないため、載荷梁と載荷装置の架台に反曲 点位置をピン接合とした柱部材を挟み込むことで、柱部材の端部に 塑性化が生じないようにする(図4)。また、床部材の接合方法と設 置範囲を考慮し試験体の規模を考える。床部材の接合方法について は、解体性を考慮した接合とする。さらに、完全合成梁を目標とし て施工するため、接合部の引抜きとせん断を安全側に考慮したピッ チでの接合とする。床部材の設置範囲は、梁部材に対してのコンク リート床の有効幅までとする。

\section{2 試験体設定}

試験体の設定にあたっては、図5に示すような5階建ての事務所ビ ルを想定したサステナブルビル構造システムに適しているとされる チューブ構造モデルに対して、地動最大速度 $0.75 \mathrm{~m} / \mathrm{s}$ 相当の地震波 を入力した際に応答が一番大きい外周構造の部材周辺を抜き出す。 試験体の規模は載荷装置の規模を考慮し、チューブ構造モデルの縮 尺1/2.5とする。その際に、構造性能の影響が大きい断面積を断面形 状がほぼ同等の縮尺 $1 / 2.5$ とし、規模は正確に縮尺 $1 / 2.5$ とする。鋼棒 の初期張力は引張試験により得られた降伏荷重の $1 / 3 の$ 值と寸る。

\section{3 試験体}

試験体は図 3 に示すような高さ $1,200 \mathrm{~mm}$ 、幅 $4,800 \mathrm{~mm}$ 、奥行 1,200mmの床なしと床ありの2体とする。この図において点線内を $\mathrm{A}$ 部、B 部とする。各試験体の部材、機械的性質を表 1 に示す。

床あり試験体の床部材は、厚さ $1.2 \mathrm{~mm}$ のキーストンプレートに普 通コンクリートを打ち込み、スラブ部分の有効厚さはチューブ構造 モデルにおいて $150 \mathrm{~mm}$ と設計されていたので、縮尺 $1 / 2.5$ の $60 \mathrm{~mm}$ とする。床スラブの配筋は入れないものとする。

床の有効幅は、床部材のスラブ部分の有効厚さの 12 倍とする。床 部材の接合部詳細を図6に示す。梁部材フランジ下にボルトのナッ 卜部分を露出させ、床部材の取り外しが容易なボルト接合とする。 ボルトは径 $10 \mathrm{~mm}$ を使用し、配置は 1 スパン内に 8 本とする。

また、床の有効幅分を支えるために、梁の両側を片持ち梁として いるが、実験結果の考察の対象は両柱の内側の接合部とする。

\section{4 載荷計画}

図 4 に実験装置を、写真 1 に載荷状況を示す。試験体は、各柱部材 両端をピン支持とし、面外方向変位を拘束する治具を設置する。ま た、載荷梁に取り付けられたアクチュエータを用い、変位制御によ る静的正負交番漸増繰返しを行う。
載荷の方向は、図4に表記した十方向から始める。以下、十方向 を圧縮側、一方向を引張側とする。また、層間変形角に対応させた 変位を制御目標とし、図7 に示寸載荷履歴で正負交番2往復とする。

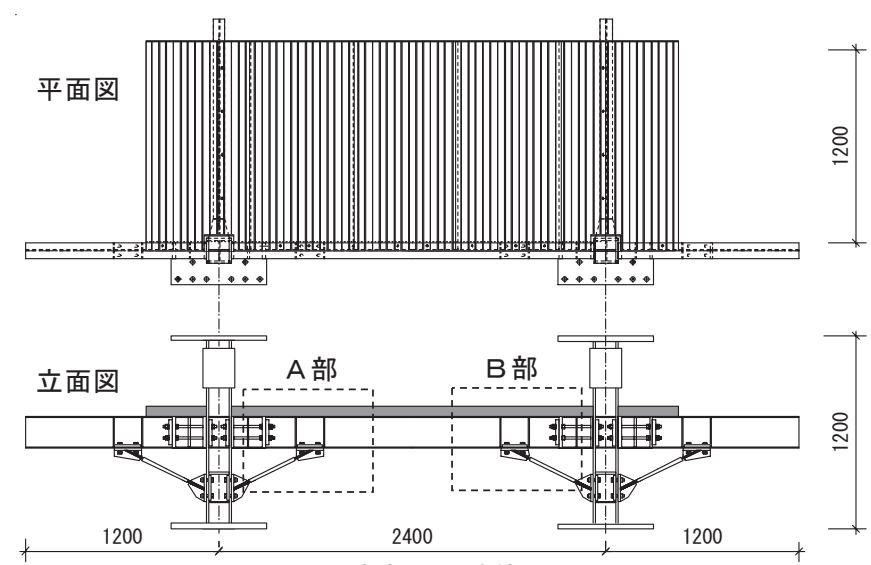

図 3 床あり試験体

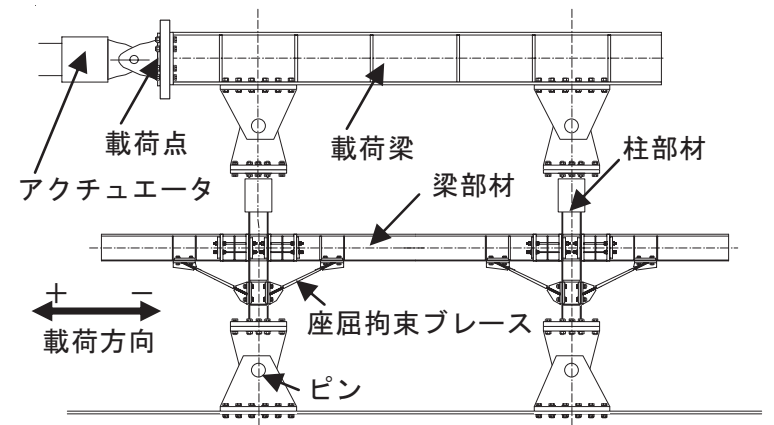

図 4 実験装置

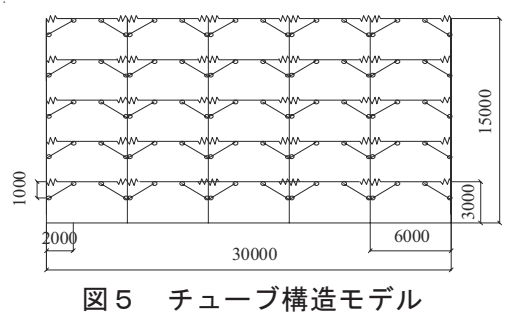

表 1 試験体部材

\begin{tabular}{|c|c|c|c|c|}
\hline & $\begin{array}{l}\text { 寸法 } \\
(\mathrm{mm})\end{array}$ & 材料 & \begin{tabular}{|c} 
降伏応力度 \\
$\left(\mathrm{N} / \mathrm{mm}^{2}\right)$
\end{tabular} & $\begin{array}{c}\text { 最大応力度 } \\
\left(\mathrm{N} / \mathrm{mm}^{2}\right)\end{array}$ \\
\hline 柱 & $\mathrm{H}-150 \times 150 \times 7 \times 10 \times 1200$ & SS400 & 311 & 438 \\
\hline 梁 & $\mathrm{H}-200 \times 100 \times 5.5 \times 8 \times 4800$ & SS400 & 278 & 419 \\
\hline ブレース & $P L-48 \times 4.5$ & SPHC & 241 & 318 \\
\hline 鋼棒 & $\phi 13$ (材長 $160 \mathrm{~mm}$ ) & S45C & 635 & 819 \\
\hline コンクリート & - & Fc24 & - & 42.5 \\
\hline
\end{tabular}

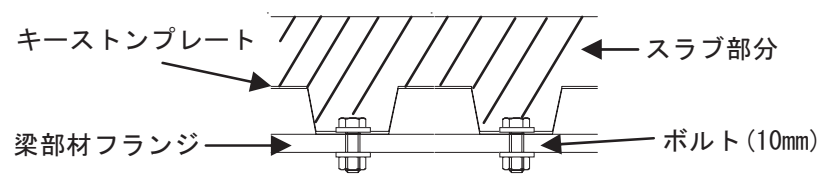

図 6 床部材接合部詳細

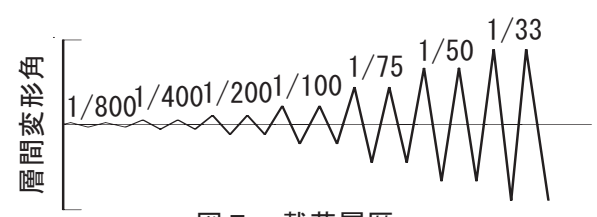

図 7 載荷履歴 


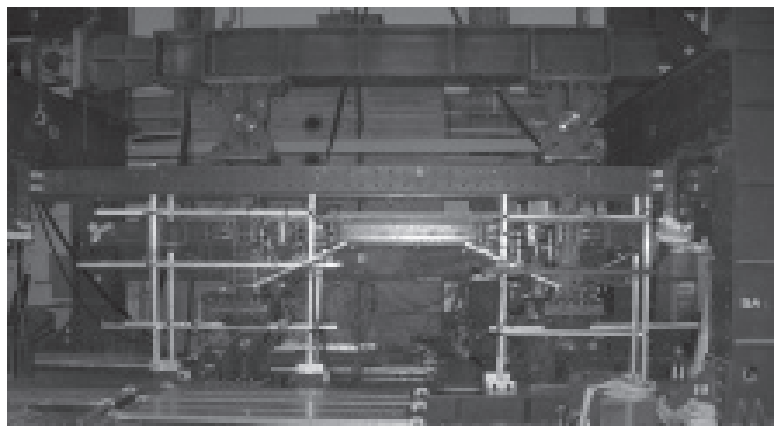

写真 1 載荷状況

\section{4. 実験結果}

\section{1 全体挙動}

両試験体の荷重と回転角の関係を図8 8 示す。両試験体ともに安 定した履歴ループを描き、最終状態である回転角 $0.03 \mathrm{rad}$ (層間変形 角 $1 / 33$ 相当)まで急激な耐力低下が生じることなく載荷を終了した。 また、両試験体ともに梁の横座屈はなく、主架構に大きな損傷は生 じていない。

床なし試験体の圧縮側の最大荷重は64.5kN、引張側の最大荷重は $51.8 \mathrm{kN}$ である。床あり試験体の圧縮側の最大荷重は $58.7 \mathrm{kN}$ 、引張側 の最大荷重は57.2kNである。また、初期張力導入による柱梁間の材 間圧縮力が解消された後、写真 2 に示すように、柱梁接合部の離間 が確認できた。床あり試験体は、写真3に示すように両柱部材周り のスラブ部分に生じたクラックとキーストンプレートの変形により 床部材の形状が変化し、床部材と梁部材が剥離した。

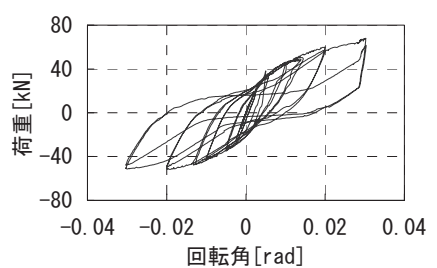

a）床なし試験体

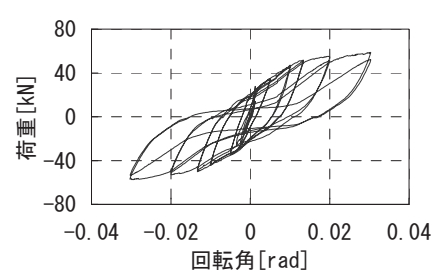

b) 床あり試験体
図8 荷重と回転角の関係

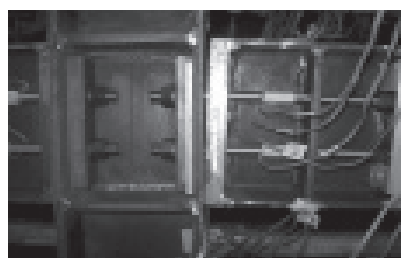

a）床なし試験体

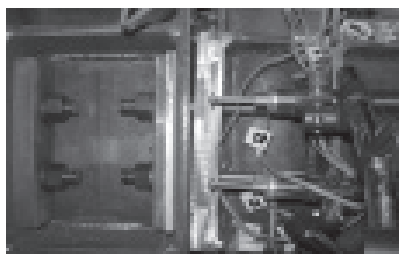

b）床あり試験体
写真 2 柱梁接合部離間状況

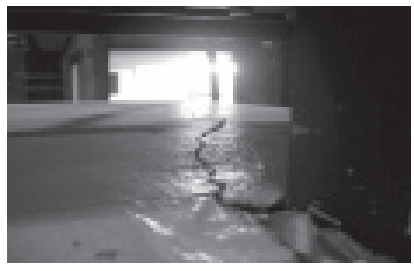

a) クラック

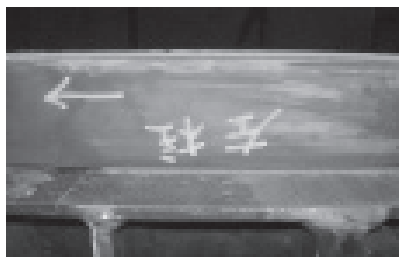

b）プレート変形
写真 3 床部材最終状況

\section{2 鋼棒}

両試験体 $\mathrm{A}$ 部接合部の上側と下側の鋼棒について、それぞれ 2 本 の平均の歪度と回転角の関係を図9に示寸。
層間変形角 $1 / 200$ に相当する、回転角 $0.005 \mathrm{rad}$ (図 9 一点鎖線部)以 上における各鋼棒の歪度の増加は、鋼棒の初期張力が解消し柱梁接 合部が離間したことを示す。

床なし試験体の鋼棒の引張歪度の最大値は上側で1. $45 \%$ 、下側で は $1.01 \%$ である。床あり試験体の鋼棒の引張歪度の最大值は上側で 1. 37\%、下側では1.28\%である。床を設置した影響で梁の剛性が高 くなり中立軸が移動するため、上側では床なし試験体、下側では床 あり試験体の歪度が大きくなる。

両試験体ともに、座屈拘束ブレースを設置している側である下側 の鋼棒に比べて、上側の方が歪度が大きい。また、歪度の最小值は、 床なし試験体では上側で $0.00 \%$ 、下側では-0.07\%であり、床あり試 験体では上側で $0.13 \%$ 、下側では $0.09 \%$ であ。床なし試験体では 鋼棒に圧縮歪が生じているが、床あり試験体では引張歪のみが生じ ている。
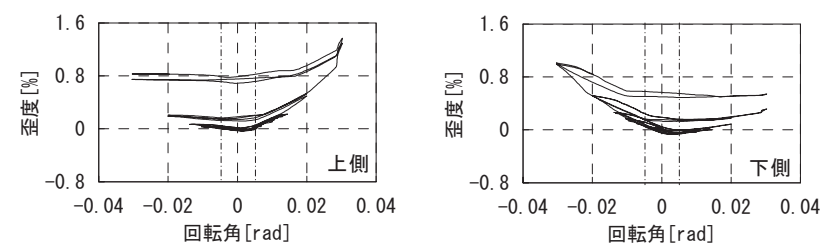

a）床なし試験体
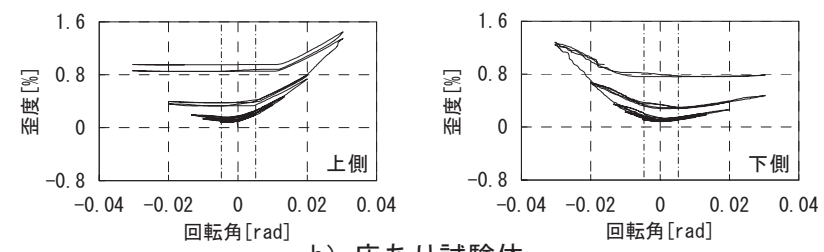

b）床あり試験体

図 9 鋼棒の歪度と回転角の関係

\section{3 座屈拘束ブレース}

両試験体の $\mathrm{A}$ 部と B 部の荷重と座屈拘束ブレースの軸変位の関 係を図10に示す。

床なし試験体では、A部の座屈拘束ブレースは、最終状態である 層間変形角 $1 / 33$ (図10a)A部楕円部)で部材座屈した。しかし、B 部の 座屈拘束ブレースが A 部の耐力低下分を負担したので、架構全体で は安定した挙動となる。図10a) B 部楕円部は荷重が増加せず、軸変 位のみが増加しているが、これは座屈拘束ブレースの変形が進み、 計測器での測定が不安定になったからである。

床あり試験体は、変位の乱れが生じることなく載荷を終了した。
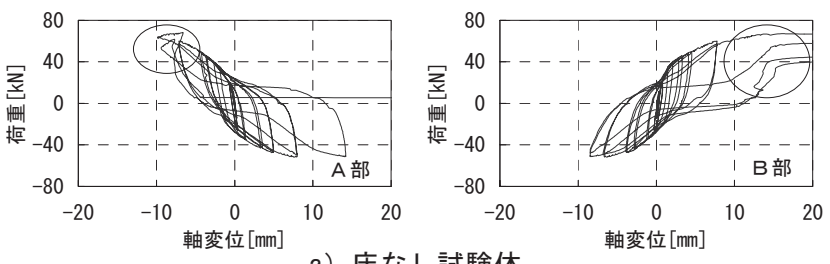

\section{a）床なし試験体}
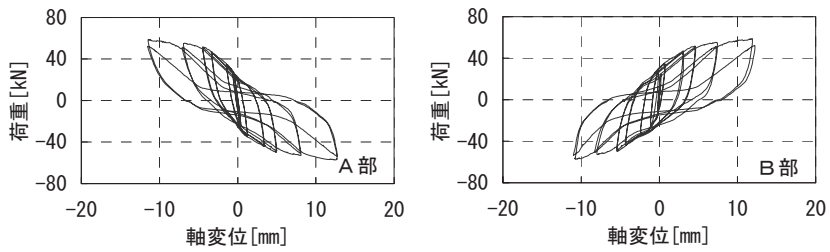

b）床あり試験体

図 10 荷重と座屈拘束ブレースの軸変位の関係 


\section{5. 実験の考察}

図8より、柱梁接合部が離間を始めるまでの架構全体の初期剛性 は、床なし試験体に比べて床あり試験体の方が $15 \%$ 程度高くなって いる。これは、床部材の設置の影響により梁部材の剛性が高くなっ たからである。また、最終剛性は両試験体でほぼ同等となっている。

これは、終局状態において床あり試験体の床部材と梁部材に剥離が 生じたことにより、梁部材の剛性が両試験体で同等になったからで ある。

図 9 に示寸両試験体 $\mathrm{A}$ 部の上側と下側の鋼棒の歪度の差は、座屈 拘束ブレースと床部材の設置の有無によって中立軸が移動するため、 梁部材の上側フランジと下側フランジの応力状態が異なったからで ある。

図11に示寸既往の研究2)におけるT字型試験体では鋼棒に圧縮歪 が生じている。しかし、今回の床あり試験体の鋼棒には圧縮歪が生 じていない。これは、床部材設置の影響により各鋼棒に生じる圧縮 力が初期張力分より小さくなったからである。また、梁の軸力と床 部材の影響を考慮していないT字型試験体に比べて、両試験体 $\mathrm{A}$ 部 の上側の鋼棒の歪度の最大值は小さくなっている。

図10に示すように座屈拘束ブレースの最終状態での挙動は床あ り試験体のほうが安定している。これは合成梁の効果により、床な し試験体に比べ、床あり試験体の方が梁部材の変形が軽減されたた めである。
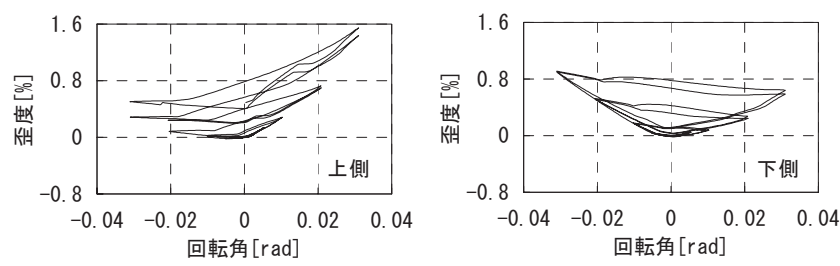

図 $11 \quad T$ 字型試験体の歪度と回転角の関係

\section{6. 解析}

T字型試験体の実験結果をもとに構築された解析法3)を用いて、今 回の試験体2体をそれぞれモデル化し、全体挙動と鋼棒の值を確認寸 るために、静的解析をする。

前提条件として、本解析では床あり試験体については、梁部材は 完全合成梁であると仮定してモデル化を行う。すべての梁部材の載 荷方向変形を同一とし、梁部材の剛性は床部材を考慮した合成梁と し、合成構造設計指針8) に従ってコンクリートと鋼材のヤング係数 比を 15 とてて算定する。

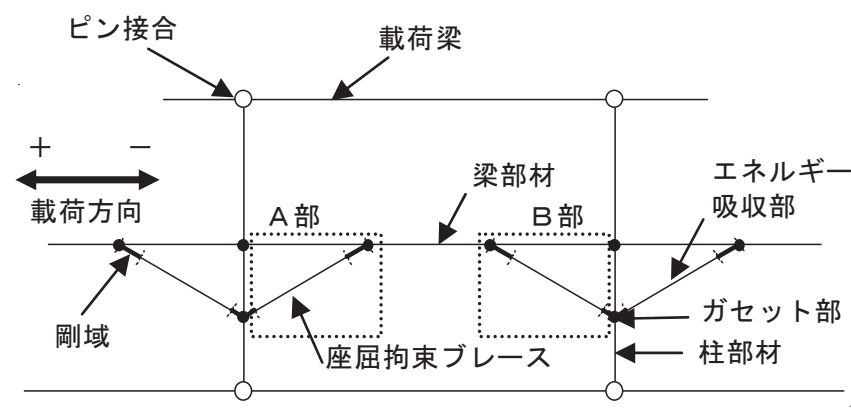

図 12 解析モデル

\section{1 解析モデル}

図 12 に図4の試験体をモデル化した解析モデルを示す。解析モデ ルは2次元フレームで構成しており、実験と同条件とするため各柱 部材両端をピン支持とし、面外方向変位を拘束する。図中の白丸は ピン接合を、太線は剛域を表し、座屈拘束ブレースはエネルギー吸 収部とガセット部に分ける。

また、解析モデルは 2 次元フレームで構成しているので、床部材 荷重は実験と同様とし、梁部材に等分布荷重として懸ける。

\section{2 解析条件}

解析は静的増分解析で行う。増分は、実験の載荷計画と同様とす るため、図7に示寸層間変形角を変位制御目標とし、正負交番 2 往復 とする。鋼材のヤング係数は $205 \mathrm{kN} / \mathrm{mm}^{2}$ とする。座屈拘束ブレース のエネルギー吸収部の降伏荷重は、座屈拘束ブレース芯材の引張試 験により得られた $241 \mathrm{kN}$ 用いる。床あり試験体については、梁部 材の曲げ剛性に関する剛性増大率は、試験体の条件から算定した結 果より 2 とする。また、鋼棒の初期張力は、実験と同様に鋼棒の降 伏荷重の $1 / 3$ の值を用いる。

\section{7. 解析結果と実験結果の比較}

\section{1 全体挙動}

床なし試験体、床あり試験体それぞれの試験体における実験結果 と解析結果を対比した荷重と回転角の関係を図13に示す。図中の実 線は解析結果、破線は実験結果である。

解析では、両解析モデルとも座屈拘束ブレースのエネルギー吸収 部が塑性化していたが、主架構は弾性範囲内に納まっていた。

図13より、両試験体ともに柱梁接合部が離間し、座屈拘束ブレ一 スが降伏し始めるまでの初期剛性と最終耐力は、実験結果と解析結 果でほぼ一致していることが分かる。座屈拘束ブレース降伏後の剛 性については、床なし試験体ではほぼ一致しているが、床あり試験 体では解析の前提条件より、実験結果よりも解析結果の剛性が高く なっている。

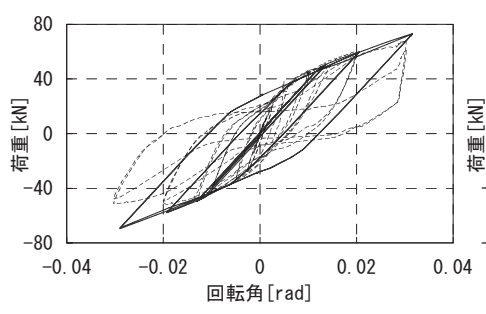

a）床なし試験体

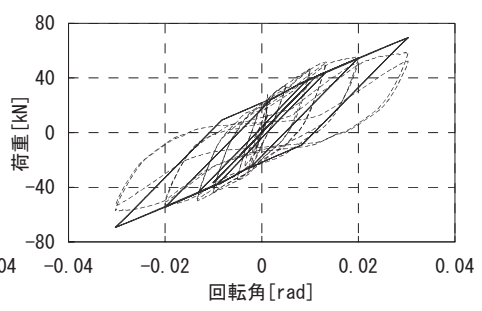

b）床あり試験体
図 13 荷重と回転角の関係

\section{2 鋼棒}

両試験体 $\mathrm{A}$ 部接合部の上側と下側の鋼棒の実験結果と解析結果 を対比した歪度と回転角の関係を図14に示寸。図中の実線は解析結 果、破線は実験結果である。

床なし試験体の解析結果は、実験結果とほぼ同様の傾向を示して いる。床あり試験体の解析結果は、層間変形角 $1 / 200$ に相当する回転 角 $0.005 \mathrm{rad}$ (図14点線部)付近まで実験結果とほぼ同等の值である。 しかし、回転角 $0.005 \mathrm{rad}$ 以降では、解析結果が実験結果を大きく下 回っている。 

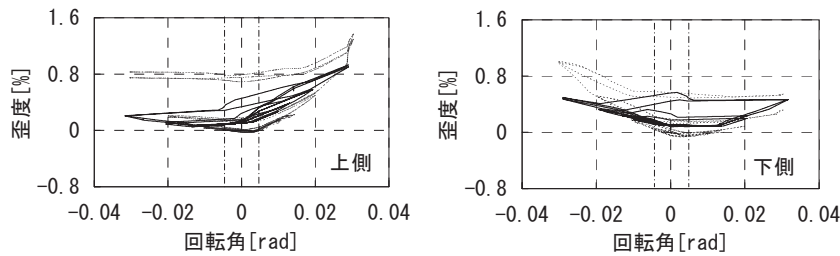

a）床なし試験体
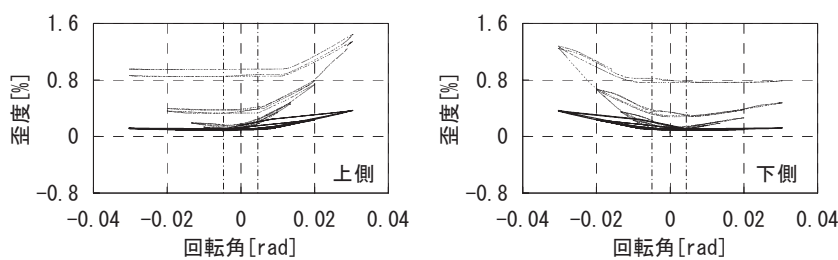

b）床あり試験体

図 14 鋼棒の歪度と回転角の関係

\section{8、設計に用いるモデル}

実験結果と解析結果の比較をすると、床あり試験体の初期剛性は、 完全合成梁として設定した解析モデルとほぼ一致する。合成梁とし ての接合部離間後の剛性は、実験では床部材と梁部材が剥離するた め梁部材の剛性は低下寸るが、解析では終局状態まで完全合成梁と して仮定し、床部材の剛性を考慮しているため、梁の剛性の低下を 表現できていない。

図14b)に示した床あり試験体の実験結果と解析結果の鋼棒の歪 度の大幅な差異は、解析においては床部材と梁部材が完全合成梁で あると仮定しており、床部材と梁部材の剥離を表現できなかったこ とによる。

つまり本研究の実験の範囲内では、床部材が梁部材と剥離するま での挙動は床ありモデルで表現できているので、許容応力度設計に 際しては、床ありモデルを用いればよいと考える。また、終局状態 に際しては、床部材が梁部材と完全に剥離すると考え、床なしモデ ルを用いればよい。

\section{9. 結}

本研究は、 1 層 1 スパンのサステナブルビル構造システムの部分 架構の床なしと床ありの試験体に対して載荷実験を行った。加えて、 試験体をモデル化したものを解析し、実験結果と解析結果の比較を 行った。これらの結果より、以下の知見を得た。

（1）床あり試験体の初期剛性は床なし試験体より $15 \%$ 程度高くなっ ており、完全合成梁として設定した解析モデルとほぼ一致する。

（2）床あり試験体の最終剛性は、終局状態においては床部材と梁部 材の剥離が生じるため、床なし試験体と同等となる。

（3）接合部の各鋼棒において、床なし試験体では圧縮歪が生じるが、 床あり試験体では圧縮歪が生じることがなく、歪度の最小值に は差がある。鋼棒に生じる圧縮力は床あり試験体のほうが小さ い。

（4）床部材が梁部材と剥離するまでは床ありモデル、終局状態につ いては床なしモデルを用いることで、既往の解析法 ${ }^{3)}$ は設計に 適用することができる。
[謝辞]

本研究の実験計画、遂行にあたり、山田哲博士（東京工業大学） に貴重な御助言を頂きました。また、本研究の解析にあたり、株式 会社構造システム 長尾真奈様に貴重な御助言を頂きました。ここに 深く感謝の意を表します。

本研究は、神奈川大学における文部科学省学術フロンティア研究 プロジェクト「災害リスク軽減を目的としたソフト・ハード融合型 リスクマネジメントシステムの構築に関する研究」の一環として実 施したものである。

\section{[参考文献]}

1）會澤貴浩、山田哲、岩田衛 : サステナブルビル構造システムの提案とその 基本特性、日本建築学会環境系論文集、第 581 号、pp.109-116、2004.7

2) 岡田健、山本重治、山田哲、岩田衛 : サステナブルビル構造システムの柱 梁接合部に関する実験、日本建築学会構造系論文集、第 591 号、pp.145-152、 2005. 5

3) 岩田衛、平田倫央、山本重治、長尾真奈 : サステナブルビル構造システム の柱梁接合部の力学モデルとその検証、日本建築学会構造系論文集、第 606 号、pp.187-193、2006. 8

4) 和田章、岩田衛、清水敬三、安部重孝、河合廣樹 : 建築物の損傷制御設計、 丸善、1998. 9

5) 竹内一郎、金尾伊織、吹田啓一郎、中島正愛 : 方杖ダンパーにより接合さ れた鋼梁の横座屈挙動と必要横補剛、日本建築学会構造系論文集、第 585 号、pp.185-192、2004.11

6) 吉敷祥一、山田哲、竹内徹、鈴木一弁、佐伯英一郎、和田章 : 損傷を梁端 下フランジの接合要素に限定する新しい鋼構造骨組 その 2 床スラブ 付き架構の実験、日本建築学会構造系論文集、第 585 号、pp.177-184、 2004. 11

7) 島有希子、平田倫央、加藤貴志、前田親範、岩田衛 : サステナブルビル構 造システムに関する研究-部分架構実験-、日本建築学会大会学術講演梗概 集 (九州) C-1 構造III、pp.991-992、2007.8

8) 日本建築学会 : 各種合成構造設計指針・同解説、1985

[2007年10月11日原稿受理２008年 1 月22日採用決定］ 